\title{
Oncological outcomes classified according to metastatic lesions in the era of molecular targeted drugs for metastatic renal cancer
}

\author{
YASUOMI SHIMIZU, TARO IGUCHI, SATOSHI TAMADA, SAYAKA YASUDA, MINORU KATO, \\ NORIKO NINOMIYA, TAKESHI YAMASAKI and TATSUYA NAKATANI
}

Department of Urology, Osaka University Graduate School of Medicine, Osaka 545-8585, Japan

Received January 9, 2018; Accepted April 23, 2018

DOI: $10.3892 / \mathrm{mco} .2018 .1614$

\begin{abstract}
Since the introduction of molecular targeted agents for the treatment of metastatic renal cell cancer (mRCC), several treatment outcomes, including those from our facilities, have been reported. However, the outcome of these drugs, classified by the metastatic organs, is not well known. The present study reported the treatment results of molecular-targeted agents as classified by the metastatic organ at Osaka City University Graduate School of Medicine. A total of 180 consecutively treated patients who had received molecular targeted agents for metastatic renal cancer for 3 or more months were retrospectively analyzed. The overall survival was calculated and compared according to the Memorial Sloan-Kettering Cancer Center (MSKCC) criteria, the number of metastatic organs, and metastatic lesions. The median overall survival of patients with mRCC treated by molecular targeted agents was 34 months. A significant difference in survival rate between groups was found according to the MSKCC criteria. Patients with single metastatic organ lived significantly longer compared with those with metastases in multiple organs. Patients with pancreatic metastasis had a good response to molecular targeted drugs. Pancreatic metastasis, the number of metastatic organs, and MSKCC criteria were independent risk factors for overall survival. Treatment of mRCC by molecularly targeted agents did not show any difference by metastatic organs except for the pancreas, although its efficacy depends on the number of metastatic organs and the MSKCC classification.
\end{abstract}

\section{Introduction}

In 2017, six molecular targeted agents were approved for the treatment of metastatic renal cell carcinoma (mRCC) in Japan (1). Results of large-scale clinical trials (2-7), as well as

Correspondence to: Dr Satoshi Tamada, Department of Urology, Osaka University Graduate School of Medicine, 1-4-3 Asahi-machi, Abeno, Osaka 545-8585, Japan

E-mail: s-tamada@med.osaka-cu.ac.jp

Key words: molecular targeted therapy, renal cell carcinoma, neoplasm, metastasis, pancreas from our institution (8), and other investigators in Japan (9-12) have reported real-world clinical data showing an improvement in the survival rate of patients with mRCC. However, it is uncertain for which type of patient will this treatment be effective. Differences in survival rates according to the Memorial Sloan Kettering Cancer Center (MSKCC) criteria (13) and the International Metastatic Renal Cell Carcinoma Database Consortium (IMDC) model (14) are being studied. Motzer et al reported that Eastern Cooperative Oncology Group performance status, serum hemoglobin level, time from diagnosis to treatment, and corrected calcium, alkaline phosphatase, and lactate dehydrogenase levels were significant independent predictors for survival (15). It was also reported that the prognostic factors used in the MSKCC classification are robust and applicable in the contemporary era of targeted therapy. Although these models correlated well with cancer survival, only a few reports presented the survival rate as classified by metastatic organ. In the cytokine therapy era, there was minimal variation in the metastatic organ among Japanese patients $(16,17)$. Liver, bone, lymph node, and brain metastases were independent risk factors for $\mathrm{mRCC}$ due to interferon- $\alpha$ administration. However, the relationship between metastatic organ and mRCC treatment using molecular targeted drugs $(10,18,19)$ are not well studied. Therefore, we aimed to investigate the survival rate classified according to the metastatic lesion in the molecular targeted agents era for $\mathrm{mRCC}$ in Japanese patients.

\section{Patients and methods}

We retrospectively analyzed 180 consecutively treated patients who had received molecular targeted drugs for $\mathrm{mRCC}$. Regarding administration of first-line drugs, sunitinib $50 \mathrm{mg}$ was administered orally (PO) every day over 2 or 4 weeks, followed by a 1- or 2-week washout period. Dose reductions, if needed, were made in decrements of $12.5 \mathrm{mg}$. Sorafenib was administered continuously at a full dose of $400 \mathrm{mg}$ PO twice a day, with an allowed dose reduction of $200 \mathrm{mg}(2,3)$. Temsirolimus was administered at a full dose of $25 \mathrm{mg}$ div weekly (7). For second-line drugs, everolimus was administered continuously at a full dose of $10 \mathrm{mg}$ PO per day (4). Axitinib was administered continuously at a full dose of $10 \mathrm{mg}$ PO per day, with allowed dose escalation of up to $20 \mathrm{mg}$, and dose reduction of up to $2 \mathrm{mg}$ (20). According to the therapeutic 
strategy in our institute, sorafenib is used as the first-line therapy and sunitinib or everolimus as the second-line therapy. From 2010 onward, we usually used sunitinib as the first-line therapy, and from 2012 onward, we usually used axitinib as the second-line therapy.

We calculated the overall survival (OS), OS classified according to the MSKCC criteria (21), the number of metastatic organs, the metastatic lesion, and presence or absence of nephrectomy. OS period commenced from treatment with the initial targeted therapy. OS was estimated using the Kaplan-Meier method, and the differences were determined using the log-rank test. Cox proportional stepwise multivariate analysis was used to evaluate the association between the number of metastatic organ, metastatic site, MSKCC criteria, presence or absence of nephrectomy and OS.

Response assessment was performed by using computed tomography or magnetic resonance imaging scans every 10-12 weeks, and evaluated according to the Response Evaluation Criteria in Solid Tumors (RECIST) v.1.1, and the change in the pancreatic tumor size was calculated by the fraction of decrease or increase in the sum of the largest diameter of the target lesions (22). A P-value $<0.05$ was considered statistically significant. All statistical analyses were performed using Microsoft Excel ${ }^{\circledR}$ (Microsoft, Redmond, Washington, USA). Permission to access the database for review of the medical records of these patients was approved by the Local Research Ethics Committee at Osaka City University (approval number 3441).

\section{Results}

The median age of the patients was 67 years (range: 35-84) Other patient characteristics and treatments are shown in Table I. Patients belonging to the intermediate risk class accounted for about $50 \%$ of all risk classes. The number of metastatic organs was almost evenly allocated to single or multiple. Lungs were the most common metastatic organ, followed by lymph nodes and bone. The median OS was 34 months (Fig. 1). Fig. 2 shows the OS classified by the MSKCC criteria. Patients in the favorable group had a significantly prolonged survival than those in the other groups; conversely, the patients in the poor group had significantly shorter survival time compared to those in the other groups (favorable: Not reached; intermediate 31.0 months; poor: 11.0 months). In univariate analysis, patients who performed nephrectomy or cytoreductive nephrectomy had a significantly prolonged survival than those who did not performed. Concerning the intermediate risk class (126 patients in total), this was subdivided into Intermediate group 1 (64 patients) and intermediate group 2 (62 patients). The median age of intermediate group 1 was 67 years (range: 40-80); that of intermediate group 2 was 69 years (range: $39-83$ ). The other patient characteristics and treatments are detailed in Table II.

Patients who had a single metastatic organ lived significantly longer than those with multiple metastatic organs (Fig. 3). OS classified according to metastatic lesions was analyzed using univariate logistic regression (Table II). Patients with pancreatic metastasis had a good response to molecular targeted drugs. Other metastatic lesions did not have a significant impact on the patients' survival. In multivariate analysis,
Table I. Patients characteristics and treatments $(\mathrm{N}=180)$.

\begin{tabular}{|c|c|c|}
\hline Characteristics & No. of patients & Percentage \\
\hline \multicolumn{3}{|l|}{ Sex } \\
\hline Male & 140 & \\
\hline Female & 40 & \\
\hline Age, years (median) & 66 & range, $35-84$ \\
\hline \multicolumn{3}{|l|}{ MSKCC } \\
\hline Favorable & 44 & $24.3 \%$ \\
\hline Intermediate & 99 & $55.2 \%$ \\
\hline Poor & 37 & $20.5 \%$ \\
\hline \multicolumn{3}{|c|}{ No. of metastatic organ } \\
\hline Single & 98 & $54.1 \%$ \\
\hline Multiple & 82 & $45.9 \%$ \\
\hline \multicolumn{3}{|l|}{ Sites of metastasis } \\
\hline Lung & 127 & $46.7 \%$ \\
\hline Lymph node & 54 & $20.0 \%$ \\
\hline Bone & 51 & $18.8 \%$ \\
\hline Pancreas & 14 & $5.1 \%$ \\
\hline Liver & 13 & $4.8 \%$ \\
\hline Brain & 13 & $4.8 \%$ \\
\hline \multicolumn{3}{|l|}{ Prior nephrectomy } \\
\hline Yes & 165 & $91.6 \%$ \\
\hline No & 15 & $8.4 \%$ \\
\hline \multicolumn{3}{|l|}{$\begin{array}{l}\text { Molecular targeted } \\
\text { agents }\end{array}$} \\
\hline \multicolumn{3}{|l|}{$1 \mathrm{st}$} \\
\hline Sunitinib & 108 & \\
\hline Sorafenib & 66 & \\
\hline Temsilorimus & 6 & \\
\hline \multicolumn{3}{|l|}{ 2nd } \\
\hline Everolimus & 30 & \\
\hline Axitinib & 33 & \\
\hline Sunitinib & 20 & \\
\hline Temsilorimus & 14 & \\
\hline Sorafenib & 2 & \\
\hline \multicolumn{3}{|l|}{$3 \mathrm{rd}$} \\
\hline Everolimus & 21 & \\
\hline Sunitinib & 7 & \\
\hline Axitinib & 7 & \\
\hline Sorafenib & 5 & \\
\hline Temsirolimus & 5 & \\
\hline Pazopanib & 3 & \\
\hline \multicolumn{3}{|l|}{ 4th } \\
\hline Everolimus & 21 & \\
\hline Sunitinib & 7 & \\
\hline Axitinib & 7 & \\
\hline Sorafenib & 5 & \\
\hline Temsirolimus & 5 & \\
\hline Pazopanib & 3 & \\
\hline \multicolumn{3}{|l|}{5 th } \\
\hline Axitinib & 3 & \\
\hline Sorafenib & 2 & \\
\hline
\end{tabular}

MSKCC, Memorial Sloan Kettering Cancer Center. 
Table II. Results of the Cox proportional stepwise multivariate analysis for the association between the clinicopathological variables and cause specific survival.

\begin{tabular}{|c|c|c|c|c|c|}
\hline \multirow[b]{2}{*}{ Comparison } & \multirow{2}{*}{$\begin{array}{l}\text { Overall survival } \\
\text { (months) (median) }\end{array}$} & \multicolumn{2}{|c|}{ Unadjusted } & \multicolumn{2}{|c|}{ Adjusted } \\
\hline & & $\mathrm{HR}(95 \% \mathrm{CI})$ & P-value & HR $(95 \% \mathrm{CI})$ & P-value \\
\hline Lung vs. other organs & 31.0 vs. 34.0 & $1.03(0.74-1.42)$ & 0.846 & & \\
\hline Lung only vs. other organs & 36.0 vs. 31.0 & $0.66(0.40-1.07)$ & 0.097 & & \\
\hline Pancreas vs. other organs & not reached vs. 31.0 & $0.20(0.04-0.80)$ & 0.024 & $0.22(0.05-0.94)$ & 0.042 \\
\hline Brain vs. other organs & 15.0 vs. 34.0 & $1.66(0.81-3.38)$ & 0.163 & & \\
\hline Lymph node vs. other organs & 28.0 vs. 34.0 & $1.15(0.76-1.74)$ & 0.496 & & \\
\hline Liver vs. other organs & 15.0 vs. 34.0 & $1.880 .83-4.26)$ & 0.129 & & \\
\hline Bone vs. other organs & 15.0 vs. 34.0 & $1.23(0.80-1.89)$ & 0.334 & & \\
\hline Single organ vs. multiple organs & 44.4 vs. 32.3 & $0.53(0.33-0.84)$ & 0.007 & $0.51(0.33-0.82)$ & 0.005 \\
\hline \multicolumn{6}{|l|}{ MSKCC } \\
\hline Favorable vs. others & not reached vs. 26.0 & $0.07(0.02-0.25)$ & $<0.001$ & $0.10(0.03-0.33)$ & $<0.001$ \\
\hline Poor vs. others & 12.0 vs. 53.0 & $4.21(2.52-7.02)$ & $<0.001$ & $2.33(1.39-3.93)$ & 0.001 \\
\hline \multicolumn{6}{|l|}{ Nephrectomy } \\
\hline Yes vs. no & 35 vs. 13 & $0.46(0.23-0.93)$ & 0.030 & & \\
\hline
\end{tabular}

MSKCC, Memorial Sloan Kettering Cancer Center.

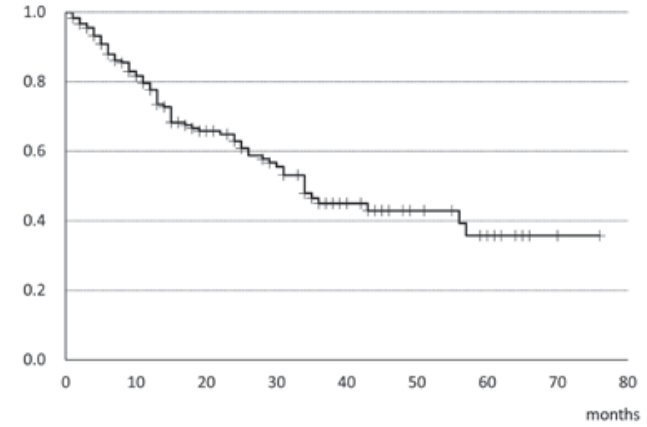

Figure 1. Overall survival of all patients with metastatic renal cell carcinoma after receiving molecular targeted drugs.

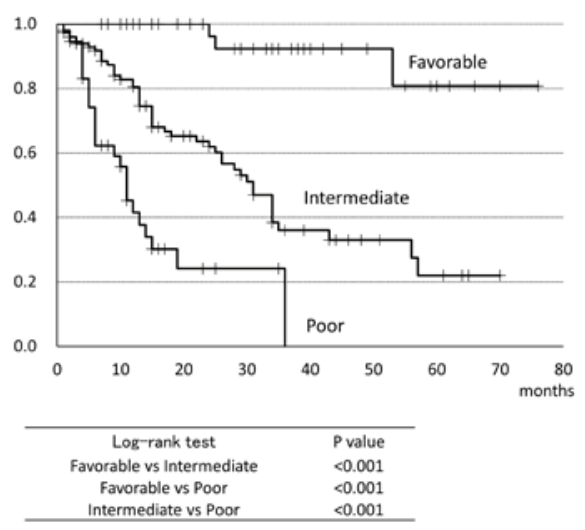

Figure 2. Overall survival according to the Memorial Sloan-Kettering Cancer Center criteria.

pancreatic metastasis, the number of metastatic organs, and MSKCC criteria were independent risk factors for OS.

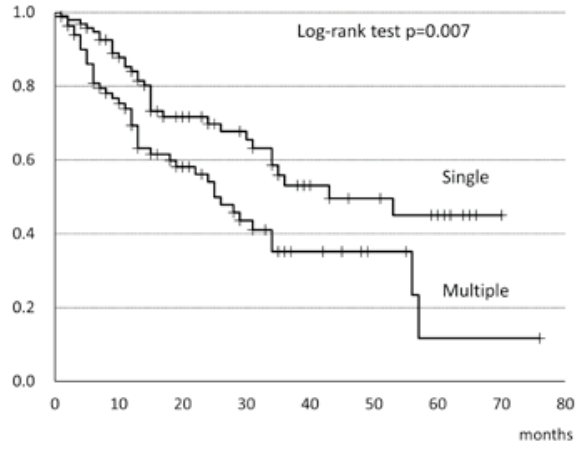

Figure 3. Overall survival according to single or multiple metastatic organs.

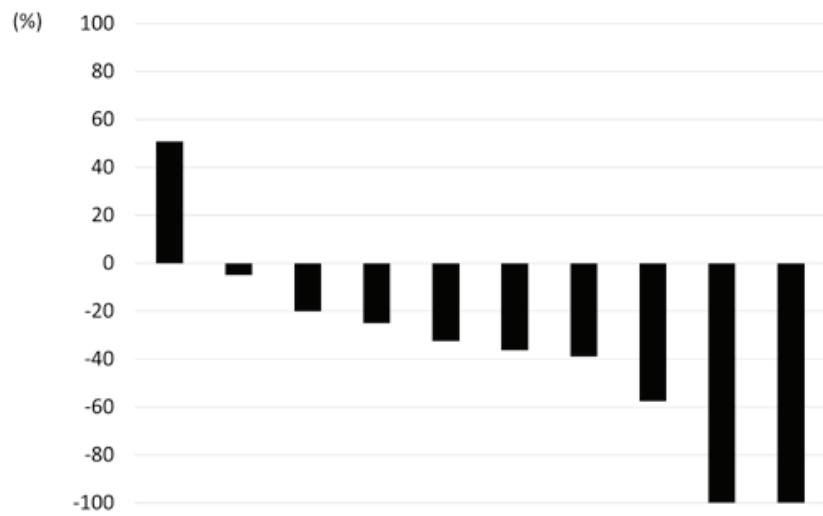

Figure 4. Maximal percentage changes in pancreatic tumor size from baseline in the 10 evaluable patients with pancreatic metastasis.

Next, we focused on pancreatic metastasis due to RCC. The characteristics of patients with pancreatic metastasis and other metastasis are shown in Table III. Three out of 14 cases 
Table III. Characteristics of patients with or without pancreatic metastasis.

Pancreatic metastasis $(\mathrm{N}=14)$

Other metastasis $(\mathrm{N}=166)$

P-value

Other metastatic organs

$\begin{array}{lcc}\text { Lung } & 10 & 117 \\ \text { Liver } & 1 & 12 \\ \text { Brain } & 1 & 11 \\ \text { Lymph node } & 4 & 50 \\ \text { Bone } & 3 & 48 \\ \text { Others } & 6 & 27 \\ \text { None } & 3 & -\end{array}$

Time from diagnosis to metastasis (months)

$81(1.5-182.5)$

$37.4(0-232.4)$

0.004

had metastases confined only to the pancreas; however, all the 3 cases had multiple pancreatic metastases in pancreatic head and there was no indication for surgical resection. In patients with pancreatic metastasis, the time from diagnosis to metastasis was significantly longer than in cases with other metastasis (unpaired t test, Welch's test). The maximum reduction from the baseline of the pancreatic tumors in the 10 evaluable patients is shown in Fig. 4. Partial remission was achieved in 6 cases.

\section{Discussion}

Treatment of mRCC has changed over the last few years, and treatment by molecular targeted drugs has become common (2-4,6,7,20). Although a number of treatment outcomes have been reported in the real-world setting $(10,23)$, there are only few reports on the treatment outcomes classified according to metastatic lesion (19). We retrospectively investigated the treatment outcome by metastatic lesion with molecular targeted drugs, and consequently, identified that pancreatic metastasis had better response compared to metastasis to other organs in the molecular targeted therapy era.

In the cytokine therapy era, there was minimal variation in the metastatic organ in Japanese patients (17). It was reported that lymph node, bone, hepatic, and brain metastasis correlated with progression on univariate analysis, but not on multivariate analysis. Shinohara et al (16) reported that liver or bone metastasis were independent risk factors. In the targeted therapy era, McKay et al reported that the presence of bone and liver metastasis had a negative impact on survival (19), and another report indicated that lymph node metastases was associated with poor prognosis in mRCC patients treated with targeted therapy (24). In Japanese patients, liver metastasis was an independent factor for OS (10). However, patients with pancreatic metastasis were very few among the population, and the relationship between survival and pancreatic metastasis was not studied in these previous studies. Yuasa et al reported that the pancreatic metastasis $(\mathrm{N}=20)$ occurs a long time (median 7.8 years) after nephrectomy, and that the OS of these patients is long (median not reached, 10 year survival rate; 80\%) (25), although, among 20 patients, only 6 patients were treated by molecular targeted drugs. Only Grassi et al (26) and Kalra et al (27) reported that pancreatic metastasis is an independent prognostic vari- able in the targeted therapy era. We also identified that OS of patients with pancreatic metastasis was longer than that of those with metastasis to other organs (not reached vs. 31 months, respectively) in Japanese patients. According to our findings, the reason that pancreatic metastasis might carry good prognosis is that pancreatic metastasis occurred late, showed good response to molecular targeted drugs, and few patients were classified to have poor prognosis according to the MSKCC criteria. In fact, our study showed that time to pancreatic metastasis was longer than that to other metastases (81 vs. 37.4 months, respectively), and $60 \%$ of patients with pancreatic metastasis achieved partial response. Moreover, no patients with pancreatic metastasis were classified as poor risk in our study population. As opposed, Chrom et al (28) recently reported that the presence of pancreatic metastasis was not an independent prognostic factor.

OS for patients with mRCC treated by molecular targeted drugs was 34 months, this result is comparable to other reports by Japanese investigators $(10,12)$. According to the MSKCC criteria (13), survival rates in each group were clearly stratified. IMDC criteria, which is another risk classification, is now often adapted to mRCC; however, some of our study participants had no available neutrophil/lymphocyte ratio, especially those who were diagnosed before 2010; hence, we did not investigate the IMDC risk. Although MSKCC criteria was established in the cytokine therapy era, our results showed that it can be applied efficiently, even in the era of molecular targeted drugs (21).

Next, we investigated the relationship between the number of metastatic organ and OS. OS for patients who had one metastatic organ was superior to those with multiple organs. Gerlinger et al mentioned that intratumor heterogeneity can lead to underestimation of the tumor genomics landscape portrayed from single tumor-biopsy samples, and may present major challenges to personalized-medicine and biomarker development (29). Therefore, it can be said that it is a reasonable result that the prognosis is better if the metastatic lesion is in a single organ. As might be expected, a single metastasis in a single organ must be enucleated because complete resection of RCC metastases may be associated with log-term survival $(30,31)$, and we also performed metastatectomy in such cases. In this study, the patient recruited was inoperable due to the presence of multiple metastases in a single organ. 
Despite that the cases who underwent metastasis resection were not included, the prognosis was better in the single organ metastasis group than in the multiple organ group; it is said that early detection and prompt treatment of metastasis are useful.

This study was a retrospective study and thus has certain limitations. Treatment strategy for mRCC patients is changing across time, so there is minimum variation due to the class of molecular targeted drugs. Treatment with immune checkpoint inhibitors has also increased, and future investigation is necessary.

In conclusion, the presence of pancreatic metastasis in patients with mRCC treated with molecular targeted therapy has a positive impact on survival. The site of metastasis may possibly be used for risk-stratification of patients with mRCC.

\section{Acknowledgements}

Not applicable.

\section{Funding}

No funding was received.

\section{Availability of data and materials}

The datasets during and/or analysed during the current study available from the corresponding author on reasonable request.

\section{Authors' contributions}

YS and ST conceived and designed the study and were major contributors in writing the manuscript. TI, MK, NN, TN and TY designed the study and revised the manuscript. SY analyzed and interpreted the data.

\section{Ethics approval and consent to participate}

Permission to access the database for review of the medical records of these patients was approved by the Local Research Ethics Committee at Osaka City University (approval no. 3441).

\section{Consent for publication}

Not applicable.

\section{Competing interests}

Dr Satoshi Tamada received remuneration for a lecture from Pfizer Japan (Tokyo, Japan), Bayer Japan (Tokyo, Japan) and Novartis Pharma Japan (Tokyo, Japan). The other authors have declared that they have no competing interests.

\section{References}

1. Shinohara $\mathrm{N}$ and Abe T: Prognostic factors and risk classifications for patients with metastatic renal cell carcinoma. Int $\mathrm{J}$ Urol 22: 888-897, 2015.
2. Escudier B, Eisen T, Stadler WM, Szczylik C, Oudard S, Siebels M, Negrier S, Chevreau C, Solska E, Desai AA, et al: Sorafenib in advanced clear-cell renal-cell carcinoma. N Engl J Med 356: 125-134, 2007.

3. Motzer RJ, Hutson TE, Tomczak P, Michaelson MD, Bukowski RM, Rixe O, Oudard S, Negrier S, Szczylik C, Kim ST, et al: Sunitinib versus interferon alfa in metastatic renal-cell carcinoma. N Engl J Med 356: 115-124, 2007.

4. Motzer RJ, Escudier B, Oudard S, Hutson TE, Porta C, Bracarda S, Grünwald V, Thompson JA, Figlin RA, Hollaender N, et al: Efficacy of everolimus in advanced renal cell carcinoma: A double-blind, randomised, placebo-controlled phase III trial. Lancet 372: 449-456, 2008.

5. Rini BI, Escudier B, Tomczak P, Kaprin A, Szczylik C, Hutson TE, Michaelson MD, Gorbunova VA, Gore ME, Rusakov IG, et al: Comparative effectiveness of axitinib versus sorafenib in advanced renal cell carcinoma (AXIS): A randomised phase 3 trial. Lancet 378: 1931-1939, 2011.

6. Motzer RJ, Hutson TE, Cella D, Reeves J, Hawkins R, Guo J, Nathan P, Staehler M, de Souza P, Merchan JR, et al: Pazopanib versus sunitinib in metastatic renal-cell carcinoma. $\mathrm{N}$ Engl J Med 369: 722-731, 2013.

7. Hudes G, Carducci M, Tomczak P, Dutcher J, Figlin R, Kapoor A, Staroslawska E, Sosman J, McDermott D, Bodrogi I, et al: Temsirolimus, interferon alfa, or both for advanced renal-cell carcinoma. N Engl J Med 356: 2271-2281, 2007.

8. Ninomiya N, Tamada S, Kato M, Yamasaki T, Iguchi T and Nakatani T: Prolonging survival in metastatic renal cell carcinoma patients treated with targeted anticancer agents: A single-center experience of treatment strategy modifications. Can J Urol 22: 7798-7804, 2015.

9. Kondo T, Takagi T, Kobayashi H, Iizuka J, Nozaki T, Hashimoto Y, Ikezawa E, Yoshida K, Omae K and Tanabe K: Superior tolerability of altered dosing schedule of sunitinib with 2-weeks-on and 1-week-off in patients with metastatic renal cell carcinoma-comparison to standard dosing schedule of 4-weeks-on and 2-weeks-off. Jpn J Clin Oncol 44: 270-277, 2014.

10. Miyake H, Miyazaki A, Harada K and Fujisawa M: Assessment of efficacy, safety and quality of life of 110 patients treated with sunitinib as first-line therapy for metastatic renal cell carcinoma: Experience in real-world clinical practice in Japan. Med Oncol 31: 978, 2014

11. Akaza H, Oya M, Iijima M, Hyodo I, Gemma A, Itoh H, Adachi M, Okayama Y, Sunaya T and Inuyama L: A large-scale prospective registration study of the safety and efficacy of sorafenib tosylate in unresectable or metastatic renal cell carcinoma in Japan: Results of over 3200 consecutive cases in post-marketing all-patient surveillance. Jpn J Clin Oncol 45: 953-962, 2015.

12. Shinohara N, Obara W, Tatsugami K, Naito S, Kamba T, Takahashi M, Murai S, Abe T, Oba K and Naito S: Prognosis of Japanese patients with previously untreated metastatic renal cell carcinoma in the era of molecular-targeted therapy. Cancer Sci 106: 618-626, 2015.

13. Motzer RJ, Bacik J, Murphy BA, Russo P and Mazumdar M: Interferon-alfa as a comparative treatment for clinical trials of new therapies against advanced renal cell carcinoma. J Clin Oncol 20: 289-296, 2002.

14. Ko JJ, Xie W, Kroeger N, Lee JL, Rini BI, Knox JJ, Bjarnason GA, Srinivas S, Pal SK, Yuasa T, et al: The International Metastatic Renal Cell Carcinoma Database Consortium model as a prognostic tool in patients with metastatic renal cell carcinoma previously treated with first-line targeted therapy: A population-based study. Lancet Oncol 16: 293-300, 2015.

15. Motzer RJ, Hutson TE, Tomczak P, Michaelson MD, Bukowski RM, Oudard S, Negrier S, Szczylik C, Pili R, Bjarnason GA, et al: Overall survival and updated results for sunitinib compared with interferon alfa in patients with metastatic renal cell carcinoma. J Clin Oncol 27: 3584-3590, 2009.

16. Shinohara N, Nonomura K, Abe T, Maruyama S, Kamai T, Takahashi M, Tatsugami K, Yokoi S, Deguchi T, Kanayama $\mathrm{H}$, et al: A new prognostic classification for overall survival in Asian patients with previously untreated metastatic renal cell carcinoma. Cancer Sci 103: 1695-1700, 2012.

17. Naito S, Yamamoto N, Takayama T, Muramoto M, Shinohara N, Nishiyama K, Takahashi A, Maruyama R, Saika T, Hoshi S, et al: Prognosis of Japanese metastatic renal cell carcinoma patients in the cytokine era: A cooperative group report of 1463 patients. Eur Urol 57: 317-325, 2010. 
18. Patil S, Figlin RA, Hutson TE, Michaelson MD, Négrier S, Kim ST, Huang $X$ and Motzer RJ: Prognostic factors for progression-free and overall survival with sunitinib targeted therapy and with cytokine as first-line therapy in patients with metastatic renal cell carcinoma. Ann Oncol 22: 295-300, 2011.

19. McKay RR, Kroeger N, Xie W, Lee JL, Knox JJ, Bjarnason GA MacKenzie MJ, Wood L, Srinivas S, Vaishampayan UN, et al: Impact of bone and liver metastases on patients with renal cell carcinoma treated with targeted therapy. Eur Urol 65: 577-584, 2014.

20. Motzer RJ, Escudier B, Tomczak P, Hutson TE, Michaelson MD Negrier S, Oudard S, Gore ME, Tarazi J, Hariharan S, et al: Axitinib versus sorafenib as second-line treatment for advanced renal cell carcinoma: Overall survival analysis and updated results from a randomised phase 3 trial. Lancet Oncol 14 $552-562,2013$

21. Motzer RJ, Bukowski RM, Figlin RA, Hutson TE, Michaelson MD, Kim ST, Baum CM and Kattan MW: Prognostic nomogram for sunitinib in patients with metastatic renal cell carcinoma. Cancer 113: 1552-1558, 2008.

22. Eisenhauer EA, Therasse P, Bogaerts J, Schwartz LH, Sargent D, Ford R, Dancey J, Arbuck S, Gwyther S, Mooney M, et al: New response evaluation criteria in solid tumours: Revised RECIST guideline (version 1.1). Eur J Cancer 45: 228-247, 2009.

23. Wahlgren T, Harmenberg U, Sandstrom P, Sandström P Lundstam S, Kowalski J, Jakobsson M, Sandin R and Ljungberg B: Treatment and overall survival in renal cell carcinoma: A Swedish population-based study (2000-2008). Br J Cancer 108: 1541-1549, 2013

24. Kroeger N, Pantuck AJ, Wells JC, Lawrence N, Broom R, Kim JJ, Srinivas S, Yim J, Bjarnason GA, Templeton A, et al: Characterizing the impact of lymph node metastases on the survival outcome for metastatic renal cell carcinoma patients treated with targeted therapies. Eur Urol 68: 506-515, 2015.

25. Yuasa T, Inoshita N, Saiura A, Yamamoto S, Urakami S Masuda H, Fujii Y, Fukui I, Ishikawa Y and Yonese J: Clinical outcome of patients with pancreatic metastases from renal cell cancer. BMC Cancer 15: 46, 2015
26. Grassi P, Verzoni E, Mariani L, De Braud F, Coppa J, Mazzaferro V and Procopio G: Prognostic role of pancreatic metastases from renal cell carcinoma: Results from an Italian center. Clin Genitourin Cancer 11: 484-488, 2013.

27. Kalra S, Atkinson BJ, Matrana MR, Matin SF, Wood CG, Karam JA, Tamboli P, Sircar K, Rao P, Corn PG, et al: Prognosis of patients with metastatic renal cell carcinoma and pancreatic metastases. BJU Int 117: 761-765, 2016.

28. Chrom P, Stec R, Bodnar L and Szczylik C: Prognostic significance of pancreatic metastases from renal cell carcinoma in patients treated with tyrosine kinase inhibitors. Anticancer Res 38: 359-365, 2018.

29. Gerlinger M, Rowan AJ, Horswell S, Math M, Larkin J, Endesfelder D, Gronroos E, Martinez P, Matthews N, Stewart A, et al: Intratumor heterogeneity and branched evolution revealed by multiregion sequencing. N Engl J Med 366: 883-892, 2012.

30. Alt AL, Boorjian SA, Lohse CM, Costello BA, Leibovich BC and Blute ML: Survival after complete surgical resection of multiple metastases from renal cell carcinoma. Cancer 117: 2873-2882, 2011.

31. Naito S, Kinoshita H, Kondo T, Shinohara N, Kasahara T, Saito K, Takayama T, Masumori N, Takahashi W, Takahashi M, et al: Prognostic factors of patients with metastatic renal cell carcinoma with removed metastases: A multicenter study of 556 patients. Urology 82: 846-851, 2013. 